\title{
8
}

\section{China's rapid emissions growth and global climate change policy}

\author{
Ross Garnaut, Frank Jotzo and Stephen Howes
}

The world has entered a period of exceptionally fast economic growth, with rapid economic development especially in China, followed by India and many other low-income countries. Early twenty-first century rates of economic growth have been even higher than the average in the 'Golden Age' of the 1950s and 1960s, so the current period could be called the 'Platinum Age' (Garnaut and Huang 2007). This rapid economic growth goes hand in hand with increasing resource use and pressure on the environment, including the build-up of greenhouse gases and resulting climate change.

In most of its first two centuries, modern economic growth was located in a small number of countries, in Western Europe, North America and Oceania, and in Japan (Maddison 2001). In the third quarter of the twentieth century, it extended into a number of relatively small economies in East Asia. A new era began in the fourth quarter of the past century, with the rapid extension of the beneficent processes of modern economic development into the heartland of the populous countries of Asia, including China, India and Indonesia. Incomes are now growing rapidly in a large proportion of the developing world.

In the absence of a major dislocation of established trends, fast growth is likely to continue for a considerable period. The contemporary slow-down in the United States and some other industrialised countries will reduce average total global growth for a while, but is unlikely to break the momentum of strong Chinese, developing-country and global growth. The first two decades of the twenty-first century will see a greater absolute increase in annual human output and consumption than was generated in the whole previous history of our species, 
and then almost that much again in the next decade to 2030 (Garnaut 2008b).

This growth is heavily dependent on energy use. Rising global energy prices can be expected to reduce substantially the growth in petroleum consumption, but not necessarily the rate of expansion of total fossil-fuel emissions, given the widespread availability of coal-the most emissions-intensive fuel. This is true for most countries that do not have stringent greenhouse gas control policies in place, and certainly for China.

China is poised to be the main engine of world growth in the next two decades. China is also one of the world's countries most reliant on coal for energy use, and therefore one of the world's most carbon-intensive countries-that is, it has one of the highest ratios of carbon dioxide emissions to energy use. China has already overtaken the United States as the largest global emitter (MNP 2008). The combination of China's large, rapidly growing economy and its carbon intensity means that in the coming years it will have an influence on greenhouse gas emissions unmatched by any other country.

Action will be needed by all major economies to limit and reduce greenhouse gas emissions to levels that limit the risk of climate change to acceptable levels. Given China's unique position, its policies will be crucial for global climate change prospects.

In this chapter, we analyse recent trends in China's growth including for energy and carbon dioxide emissions and present business-as-usual projections to 2030 for China and the world. Then we summarise recent policy developments in China and ask what kind of commitments China could and would need to undertake in a world of comprehensive climate change mitigation.

\section{Recent trends}

Carbon dioxide emitted from the combustion of fossil fuels is the largest and fastest growing greenhouse gas; it is the focus of this chapter. Through the 'Kaya identity' (Kaya and Yokobori 1997), ' carbon dioxide emissions growth $(\Delta)$ can be decomposed (to a first-order approximation) into economic growth, and growth in energy intensity (of gross domestic product, GDP) and carbon intensity (of energy)

$$
\Delta C \mathrm{O}_{2}=\Delta G D P+\Delta(\text { energy } / G D P)+\Delta\left(\mathrm{CO}_{2} \text { lenergy }\right)
$$

Summary data for these variables are presented in Table 8.1, for the world, for China and for the world excluding China. There has been a world-wide acceleration this decade in the growth of all three of GDP, energy and emissions (see also Raupach et al. 2007). ${ }^{2}$ Table 8.1 shows how of much of the recent acceleration in growth in global emissions is due to China. Global emissions fell in the 1990s 
due largely to the collapse of the transitional economies. Apart from China, emissions growth this decade (2000-05) is lower than it was in the 1970s and 1980s: 1.5 per cent compared with 1.8 per cent. With China, however, total global emissions growth this decade is 2.9 per cent-well up from the 1971-90 global average emissions growth rate of 2.1 per cent. China's carbon dioxide emissions grew by 10.6 per cent on average between 2000 and 2005-more than three times the growth rate of the 1990s. ${ }^{3}$ Fifty-five per cent of the growth in global emissions between 2000 and 2005 occurred in China.

Table 8.1 A comparison of GDP, energy and carbon dioxide emissions growth rates and elasticities for the world and China,

1971-2005

\begin{tabular}{|c|c|c|c|}
\hline World & $1971-90$ & $1990-2000$ & $2000-05$ \\
\hline Emissions growth (per cent) & 2.1 & 1.1 & 2.9 \\
\hline GDP growth (per cent) & 3.4 & 3.2 & 3.8 \\
\hline Energy growth (per cent) & 2.4 & 1.4 & 2.7 \\
\hline Energy/GDP growth (per cent) & -1.0 & -1.8 & -1.1 \\
\hline $\mathrm{CO}_{2}$ /energy growth (per cent) & -0.3 & -0.2 & 0.3 \\
\hline Energy/GDP elasticity & 0.71 & 0.43 & 0.69 \\
\hline $\begin{array}{l}\text { Emissions/energy elasticity } \\
\text { China }\end{array}$ & 0.87 & 0.82 & 1.10 \\
\hline Emissions growth (per cent) & 5.5 & 3.2 & 10.6 \\
\hline GDP growth (per cent) & 7.8 & 10.2 & 9.4 \\
\hline Energy growth (per cent) & 4.3 & 2.5 & 9.1 \\
\hline Energy/GDP growth (per cent) & -3.3 & -6.9 & -0.2 \\
\hline $\mathrm{CO}_{2}$ /energy growth (per cent) & 1.2 & 0.7 & 1.4 \\
\hline Energy/GDP elasticity & 0.55 & 0.25 & 0.97 \\
\hline $\begin{array}{l}\text { Emissions/energy elasticity } \\
\text { World excluding China }\end{array}$ & 1.29 & 1.27 & 1.16 \\
\hline Emissions growth (per cent) & 1.8 & 0.8 & 1.5 \\
\hline GDP growth (per cent) & 3.2 & 2.6 & 3.0 \\
\hline Energy growth (per cent) & 2.3 & 1.2 & 1.7 \\
\hline Energy/GDP growth (per cent) & -0.9 & -1.3 & -1.3 \\
\hline $\mathrm{CO}_{2}$ /energy growth (per cent) & -0.4 & -0.4 & -0.2 \\
\hline Energy/GDP elasticity & 0.70 & 0.48 & 0.56 \\
\hline Emissions/energy elasticity & 0.81 & 0.68 & 0.90 \\
\hline
\end{tabular}


Figure 8.1 uses the same data as Table 8.1 to explore the differences in carbon dioxide, energy and GDP relationships in China and globally. World-wide (excluding China), the ratios of carbon dioxide emitted to energy used and energy to GDP have fallen gradually and fairly smoothly. In China, in contrast, the ratio of carbon dioxide to energy has risen over time. The ratio of energy to GDP in China was stable until the late 1970s, fell sharply until about 2000, and has been roughly stable since. World-wide, carbon dioxide to GDP has fallen more sharply than either the carbon dioxide/energy or energy/GDP ratio (since both these have been in decline)-but not in China since carbon dioxide/energy has been increasing. Since 2000, GDP and energy have been growing at the same rate in China, and emissions slightly faster than both.

What has been driving the unusual trends observed in China? China's energy intensity in the 1970s was very high. During the 1980s and 1990s, major improvements were achieved in the energy efficiency of the Chinese economy. This can be traced to strong improvements in industrial energy efficiency driven by government regulation, including the shut-down of small inefficient power plants (motivated in part by concerns about local air pollution), changes in ownership of state-owned enterprises, rising energy prices and structural

Figure 8.1 Carbon dioxide emissions/GDP, energy/GDP and carbon dioxide emissions/ energy for the world and China, 1971-2005 (1971=100)

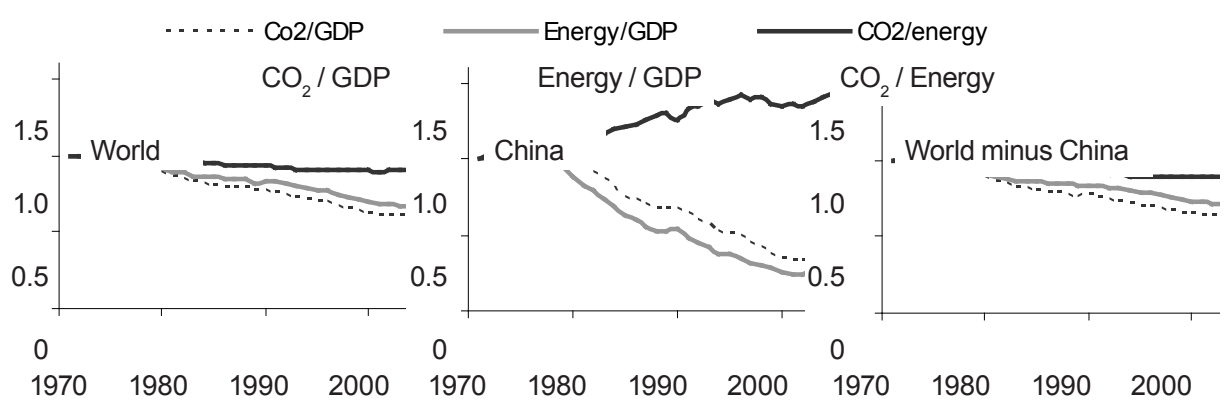

Notes: Emissions growth is carbon dioxide from the combustion of fossil fuels (excluding industrial processes). Energy growth is total primary energy supply measured in million tonnes of oil equivalent (Mtoe). GDP growth is measured using 2000 US\$ purchasing power parity (PPP).

Source: International Energy Agency (IEA), 2007b. $\mathrm{CO}_{2}$ Emissions from Fuel Combustion, International Energy Agency, Paris. 
change (Fisher-Vanden et al. 2004; Wu et al. 2005; Sinton and Fridley 2000). Many of the efficiency gains in the 1990s were, however, one-offs, and the move towards greater private-sector control of the economy weakened the emphasis on energy-saving measures. Quadrelli and Peterson (2007) report that investment in energy conservation as a share of total energy investment in China declined from 13 per cent in 1983 to 7 per cent in 1995 and to 4 per cent in 2003. China's energy-intensive industries have boomed in recent years. Between 2000 and 2006, crude steel production in China grew by an annual average of 22 per cent, pig iron grew by 21 per cent and cement grew by 13 per cent (NBS 2007a). All this has resulted in rapid energy growth in China in recent years (Figure 8.2). Between 2000 and 2005, total energy consumption grew by more than half in just five years. There has been a slight slow-down in energy growth in 2006 and 2007, but rates are still close to 10 per cent. After remaining unchanged between 2000 and 2005, energy intensity fell in 2006 by 2 per cent. ${ }^{4}$ First-half figures for 2007 indicated a fall in energy intensity of 2.8 per cent. ${ }^{5}$

The average carbon intensity of China's energy use has kept increasing. This is due largely to a changing energy mix, with growth concentrated in fossil fuels. From 1990 to 2005, coal energy demand doubled and the share of coal in total energy demand increased from 61 to 63

Figure 8.2 Energy consumption in China, levels and growth, 1978-2006

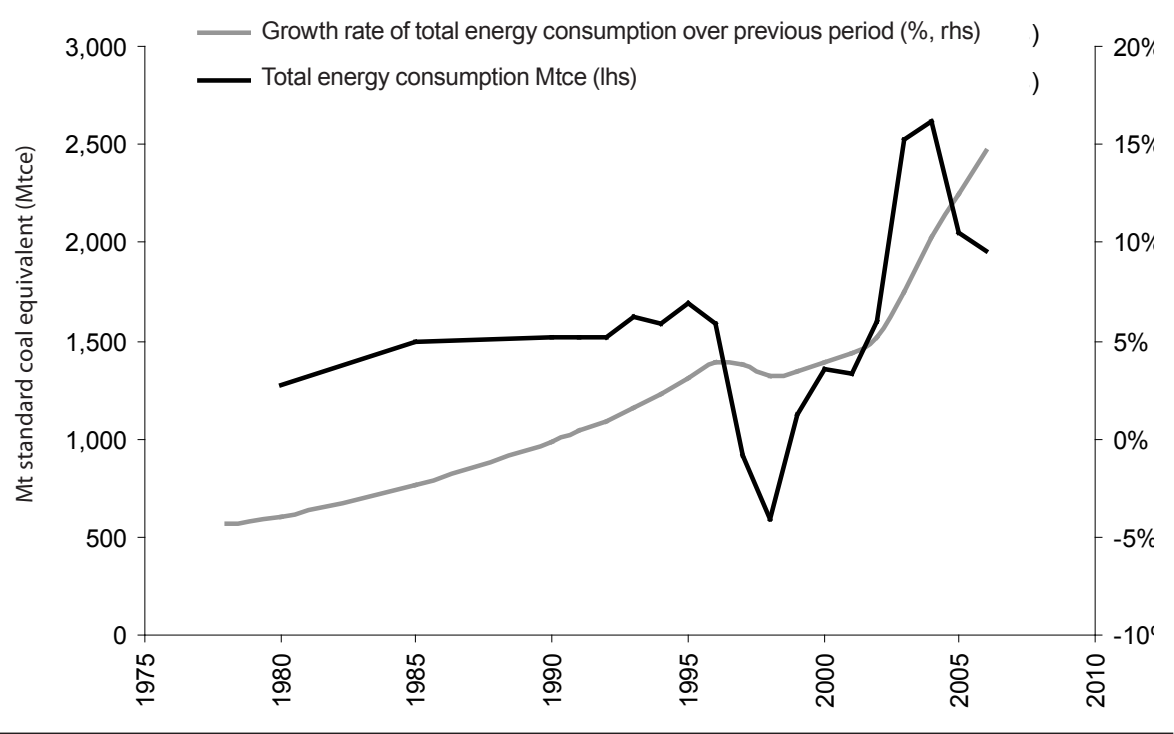

Source: National Bureau of Statistics, 2007a. 2007 China Statistical Yearbook, China Statistics Press, Beijing. 
per cent (IEA 2007a). Increased coal use is predominantly for use in power generation, which is almost 80 per cent coal based and booming; in 2006, nearly 90 per cent of new electricitygeneration capacity was coal fired. Lower or zero-emissions sources (renewable sources including hydroelectricity, nuclear power and gas) have been growing fast but from low bases or, in the case of biomass, have stagnated in absolute terms. Oil use, especially for transport, almost trebled from 1990 to 2005 , increasing its share in total energy use from 13 to 19 per cent.

\section{A business-as-usual projection}

This section projects fossil fuel-related carbon dioxide emissions to 2030 under a business-as-usual, constant-policy approach. ${ }^{6}$ Policies already in place to reduce emissions are assumed to continue, but it is assumed no new ones are put in place, even if a government has committed to do so. We start with projections from the most recent International Energy Agency (IEA) 2007 World Energy Outlook (IEA 2007a), which make use of extensive information on energy systems in a partial-equilibrium framework. Using an emissions-growth decomposition framework, we then make adjustments, based on the analysis presented in this chapter, to selected macroeconomic assumptions-namely, GDP growth in non-Organisation for Economic Cooperation and Development (OECD) countries and the intensity of energy use with regard to GDP in China. The strength of this approach is that it builds on the specialist knowledge of the IEA, and makes clear what assumptions might need rethinking. Its limitation is

that it does not capture the general-equilibrium effects that would derive from the changes in assumptions.

\section{GDP}

We review and adjust IEA (2007a) growth rates for the three most-populous developing countries-China, India and Indonesia-and for other developing and transitional regions.

Our growth forecasts for China draw on the growth-accounting framework of Perkins and Rawski (2008). As Table 8.2 shows, we accept the Perkins-Rawski projections for educationenhanced labour, and assume a figure of 3.1 per cent total factor productivity (TFP) growth for the entire period, which is the rate of TFP growth in the past decade. Perkins and Rawski assume a slow-down in the rate of capital formation, but investment rates are rising, and Garnaut and Huang (2005) argue that these are in fact likely to rise even higher than current levels. We assume investment stays at 45 per cent of GDP until 2015 and then falls to 40 per cent by 2025. Embedding these assumptions into the Perkins-Rawski framework results in projected growth of 9 per cent from 2005 to 2015 and 6.8 per cent for 2015-25 (Table 8.2). ${ }^{7}$ Considered against China's recent performance, and its good prospects for continued double-digit growth (Garnaut and Huang 2005, 2007), we consider this projection to be relatively conservative. China 
Table 8.2 Growth-accounting projections for China, 2005-25

\begin{tabular}{lcccc}
\hline & \multicolumn{2}{c}{} & & \\
Annual average & \multicolumn{2}{c}{$2005-2015$} & 2025 \\
growth (\%) & Perkins-Rawski & Platinum age & Perkins-Rawski & Platinum age \\
Labour growth (\%) & 2.0 & 2.0 & 1.0 & 1.0 \\
Capital growth (\%) & 9.8 & 11.0 & 5.6 & 7.3 \\
Capital share & 0.43 & 0.43 & 0.43 & 0.43 \\
TFP growth (\%) & 3.6 & 3.1 & 3.0 & 3.1 \\
GDP growth (\%) & 9.0 & 9.0 & 6.0 & 6.8 \\
\hline
\end{tabular}

Notes: All 'Platinum Age' (current chapter) assumptions are, unless otherwise stated, from Perkins, D. and Rawski, T., 2008. 'Forecasting China's economic growth over the next two decades', in L. Brandt and T.G. Rawski (eds), China's Great Economic Transformation, Cambridge University Press. Note that Perkins and Rawski's 3.6 per cent total factor productivity growth figure for 2005-15 is not presented as a realistic estimate, but derived by the authors to show what it would take, given their projected capital and labour growth, to achieve 9 per cent GDP growth.

Source: Garnaut, R., Howes, S., Jotzo, F. and Sheehan, P., 2008 (forthcoming). Emissions in the Platinum Age: the implications of rapid development for climate change mitigation, Background Working Paper for the Garnaut Climate Change Review, Oxford Review of Economic Policy.

has averaged about 10 per cent GDP growth per annum since 1990. The latest figures for 2006 and 2007 are for 11.6 per cent and 11.9 per cent growth, respectively (NBS 2008a). Our growth projections are, however, well above widely used international projections, including that of the IEA, which in its reference scenario has China's GDP growth at 7.7 per cent for 2005-15 and 4.9 per cent for 2015-30.

The recent acceleration of growth in the developing world has extended well beyond China. The growth acceleration is most evident from the period 2004-07, during which all developing-country regions as well as the group of transitional economies grew at 5 per cent per annum or more. We see this acceleration of growth in developing countries as owing much to better policy settings and to the spill-over effect of rapid Chinese growth-and therefore as sustainable. Based on growth accounting (Garnaut et al. 2008), we use, for India, 7.5 per cent for 2005-30 as a GDP growth projection, and for Indonesia 6.5 per cent. For developing countries other than China, India and Indonesia, we use a weighted average of IEA projections (two-thirds) and performance in the past four years (one-third).

Under the assumptions deployed, all developing and transitional countries are projected to be growing faster than they were in the latter decades of the past century, but slower than at rates observed in the past four years-with the exception of Indonesia.

\section{Energy intensity}

The IEA (2007a) projects significant falls in the energy intensities of developing 
countries from current levels. ${ }^{8}$ Although this is inconsistent with historical experience (Figure 8.3), we accept it on the grounds that high energy prices might induce greater efforts to improve energy efficiency.

Future trends in energy intensity in China are a matter for debate. This is not surprising given the variability of past trends (Figures 8.1, 8.2 and 8.3). Will the downward trend in energy intensity observed in the 1980s and 1990s resume, or is the recent cessation of that trend a permanent break?

The IEA assumes that the downward trend will resume, and that China will reduce energy intensities by 2.5 per cent per annum until 2015 , and then by 2.8 per cent to 2030 . This projection is consistent with the position of some observers that China uses energy inefficiently and has plenty of room to improve (Cooper 2004).

China's energy intensity is high if market exchange rates are used to compare economies, but less so if purchasing power parities (PPPs) are used. Moreover, the international experience does not suggest that energy intensity falls in the course of development. As Figure 8.3 shows, China has been the exception rather than the rule. In most developing countries, and as an average, the energy intensity of the economy has been remarkably constant in the past

Figure 8.3 Energy intensity in China and other developing countries, 1971-2005

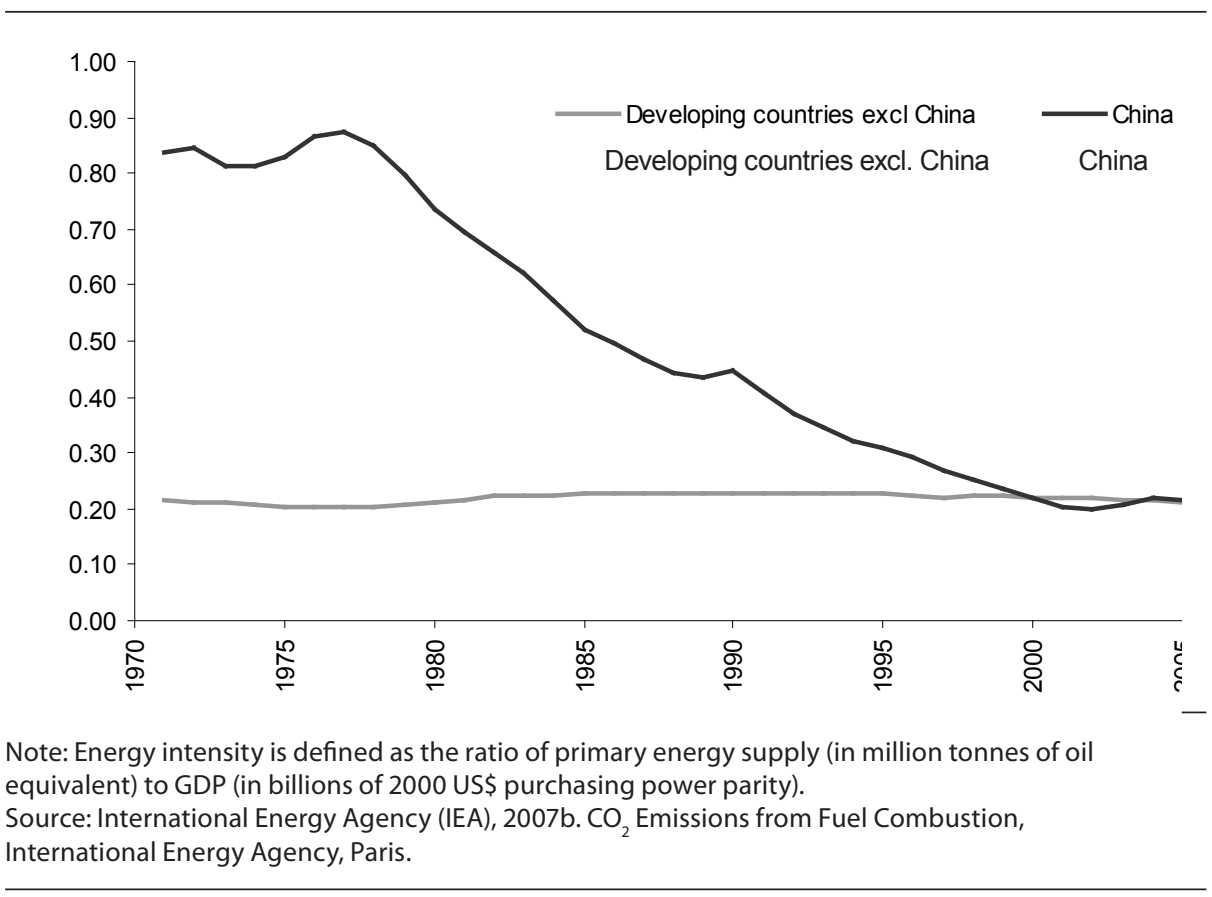


three and a half decades.

A closer examination of economies whose development path China might be thought to be following - Japan, Korea and Taiwan-similarly belies the notion that energy intensity falls as countries develop (Figure 8.4). Analysis of the historical experience of Japan, Taiwan and Korea shows only small decreases in energy intensity as per capita income increases, with energy intensity roughly flattening out at levels well above that assumed by the IEA for China in coming decades.

The IEA (2007a) argues that energy intensity will fall as the structure of the Chinese economy shifts from heavy to light industry. It is true that China has put in place a number of policies to slow the growth of energy-intensive sectors: for example, through taxes on energy-intensive exports (see the next section). The shift to heavy industry is, however, no more than would be expected as an economy develops with a high level of investment (extraordinarily high in China's case) underpinning a shift in comparative advantage towards more capital-intensive manufacturing. Energy-intensive heavy industry has been growing so fast in China that its growth will have to fall very significantly for its share in the economy to fall.

We assume that energy intensities decline at two-thirds the rate assumed by the IEA. This gives China a rate of energy-intensity reduction around the developing-country average. The

Figure 8.4 Energy intensity in China, Japan, Korea and Taiwan, 1971-2005

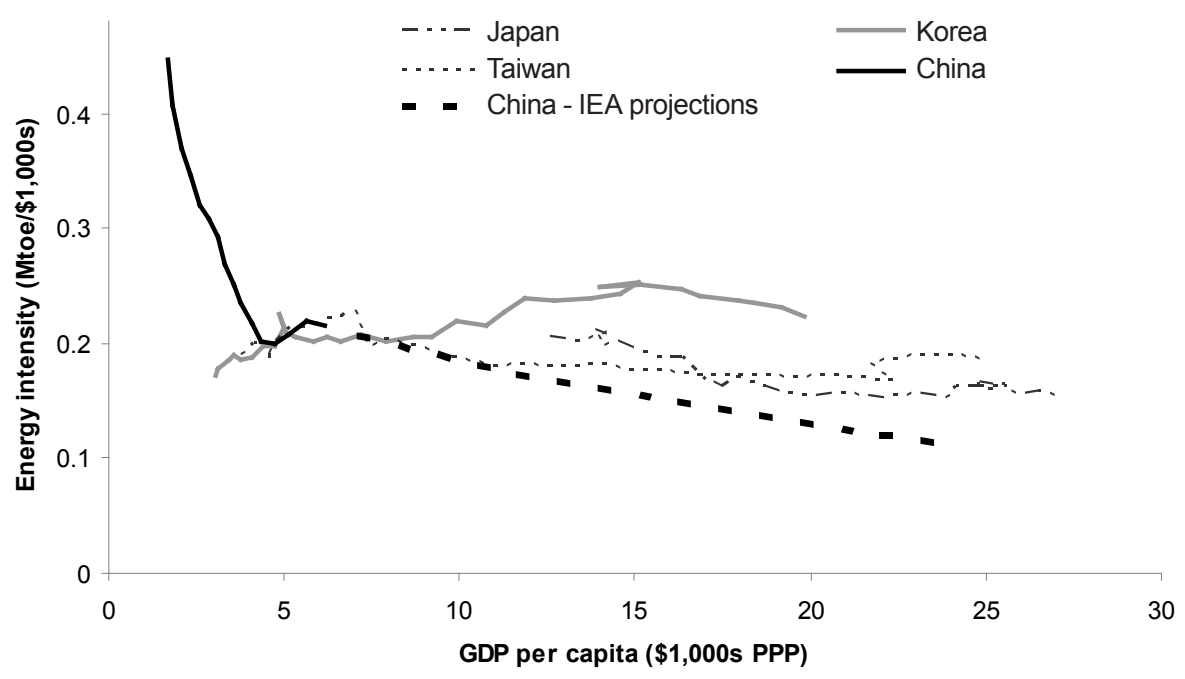

Source: Data from IEA (2007b). CO Emissions from Fuel Combustion, International Energy Agency, Paris. 
adjustment gives energy elasticities for China of 0.8 for 2005-15 and 0.7 for 2015-30, which is consistent with or below the work of Sheehan and Sun (2007), but well above the IEA's projections for the two periods of 0.66 and 0.4 , respectively.

\section{Carbon intensity}

We assume that the carbon intensities of energy use (carbon dioxide/total primary energy supply) stay broadly constant, in line with IEA projections. This is a conservative approach on two counts. First, in recent years, emission intensities have in fact been increasing in the developing world, due to the shift to coal, with a pronounced increase in carbon intensity in China. The tighter supply constraints on oil will continue to force substitution to other fuels. The prices for traded coal have increased in recent times also, but this reflects purely short-term supply constraints in mining and shipping rather than resource scarcity, and an expanded coal supply is expected to balance current excess demand.

Second, if energy use does turn out to be higher than projected by the IEA (as we argue it will), a disproportionate amount of the extra demand will be met by (emissions-intensive) coal. In particular, our projections have emissions growing at about the same rate as energy in China. If, however, the growth of coal use continues to stay high, emissions will grow faster than energy. Between 2000 and 2005, coal use in China increased on average by 11.7 per cent. In 2006, China's coal consumption grew by 11.9 per cent and, in 2007, according to preliminary estimates, it grew by 7.8 per cent (NBS 2007a, 2008b).

\section{Emissions}

Putting these assumptions together results in annual average growth in China's carbon dioxide emissions of 7.5 per cent from 2005-15, and 4.7 per cent from 2015-30. This is significantly above mainstream projections. IEA (2007a) projects emissions growth for China in these two periods of 5.4 per cent and 1.9 per cent. The IEA (2007a) 'rapid growth' scenario projects somewhat higher emissions growth for China of 6.4 per cent for 2005-15 and 2.7 per cent for 2015-30. On the other hand, the Platinum Age projections are not above the range of China-specific studies. Auffhammer and Carson (2008), in dynamic statistical models for China's emissions based on regional data up to 2004, forecast annual average carbon dioxide emissions growth of 11-12 per cent for 2001-10 (see also Sheehan and Sun, this volume).

Under business-as-usual, largely because of China's rapid emissions growth, global emissions growth will stay high. The Platinum Age projections predict 3.1 per cent annual average growth in carbon dioxide emissions from 2005-30 (Garnaut et al. 2008:Table 9). These are again above the range of official global projections. For example, the IEA (2007a) projects 2.1 per cent annual average growth in carbon dioxide emissions for this period. 
Under the Platinum Age projections, China would almost double its share in global carbon dioxide emissions, from 19 per cent in 2005 to 37 per cent in 2030 (Figure 8.5). China's emissions in this scenario would be about three times as large as the United States' at the end of the period. The share of current non-OECD countries in global emissions would be more than 70 per cent.

After 2030, China's emissions growth will slow considerably, not least because its population growth will probably turn negative thus further slowing GDP growth. However, by 2030 , it will be too late for the world to start acting on climate change. If the world does reach the levels of emissions projected in Figure 8.5 it will have locked in dangerous levels of temperature increase in subsequent decades. In any case, if the world is still not on a climate change mitigation path, other developing countries are set to take over from China after 2030 as the prime drivers of rapid emissions: first India (on its way to overtaking China as the world's most populous country and, eventually, the largest economy), and then other regions including sub-Saharan Africa.

Clearly, China's growth path in the next two decades will be decisive for global climate change. Its policies and stance in international negotiations will be increasingly important influences on the global response to climate change.

\section{China's climate change policies and goals}

Recall that the projections in the previous section are constant-policy ones, assuming no further policy action to reduce greenhouse gas emissions. In reality, however, climate change is moving up the policy agenda in China.

China's National Development and Reform Commission, in its National Climate Change Program (NDRC 2007), noted a range of observed and projected climatic changes in China, including temperature increases, changes in precipitation patterns, increases of arid areas and risks of desertification, sea-level rise, the possibility of more frequent extreme weather or climate events and the accelerated retreat of glaciers. The NDRC put forth a set of objectives, principles and policies to deal with climate change.

The principles include an emphasis on the UN Framework Convention on Climate Change's principle of 'common but differentiated responsibilities', active participation in international cooperation, equal emphasis on the mitigation of and adaptation to climate change and integration with other policies such as those for energy conservation and agricultural productivity.

Various policies and programs to reduce energy consumption have been launched or announced (NDRC 2007; Pew Center 2007). They include closing inefficient power plants to the tune of about 8 per cent of current generating capacity, closing small or outdated industrial plants, agreements for incentives for the largest 1,000 enterprises, improving end-use efficiency through standards and labelling and mandatory fueleconomy standards for cars that are more stringent than those in the United States. Specific 
Figure 8.5 Historical and projected carbon dioxide emissions levels, 1990-2030

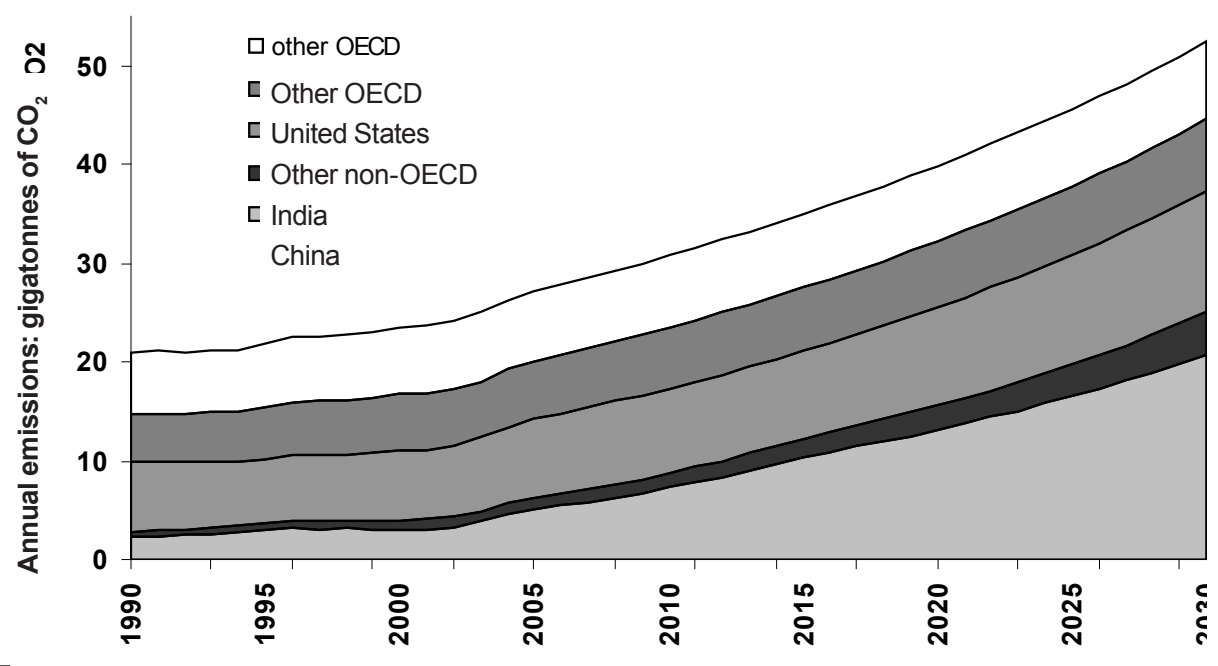

Sources: Data for 1990-2005 from International Energy Agency (IEA), 2007b. CO 2 Emissions from Fuel Combustion, International Energy Agency, Paris; Platinum Age projections from Garnaut, R., Howes, S., Jotzo, F. and Sheehan, P., 2008. Emissions in the Platinum Age: the implications of rapid development for climate change mitigation, Background Working Paper for the Garnaut Climate Change Review, forthcoming in Oxford Review of Economic Policy.

advanced processes are to be used in energy-intensive industries.

Policies also aim to change the composition of the economy. The service sector's share is to be increased, and the scale of energy-intensive industries reduced in favour of high technology and information industries. Export taxes are already levied on energy-intensive industries - at 15 per cent for a range of metals and 10 per cent for primary steel products-while import tariffs are to be reduced to 0-3 per cent (Pew Center 2007).

Reducing the energy intensity of the economy is motivated not predominantly by climate change objectives, but importantly by China's concerns about energy security (Downs 2004), and by concerns about local environmental impacts such as air pollution. It is unclear to what extent comprehensive policies to limit greenhouse gas emissions will in fact be implemented-and, even if fully implemented, they will fall a long way short of stopping the growth in China's emissions. The NDRC (2007:19) cautions that 'with [the] current level of technology development, to reach the development level of the industrialized countries, it is inevitable that per capita energy consumption and $\mathrm{CO}_{2}$ emissions will reach a fairly high level'.

On the energy-supply side, a range of policies is aimed towards lowering carbon intensity 
(NDRC 2007). The share of renewable energy sources is to be increased under the Renewable Energy Law, predominantly through a doubling of hydropower capacity. Nuclear power capacity is to be quadrupled. Within thermal power generation, the development of highefficiency coal power plants is to be accelerated, and methane arising from coal-mining is to be utilised for power generation to a greater extent. China is also involved in initiatives with the United States, Europe and Australia on carbon capture and storage.

Programs to reduce emissions are also planned or are under way beyond the energy sector, such as accelerated reforestation and the development of rice varieties that are low in methane emissions (NDRC 2007).

The target contained in China's eleventh Five-Year Plan is to reduce the energy intensity of GDP by 20 per cent from 2005 to 2010 . This is against the backdrop of a broader strategy of quadrupling GDP from 2000 to 2020, while doubling energy consumption (Development Research Center 2005, see also Sinton et al 2005), thus limiting the growth rate in energy use to approximately half the GDP growth rate. The 2005-10 target implies an average annual reduction in energy intensity of 4.4 per cent, starting from 2005 levels. Such reductions would be a drastic turn around from almost unchanged intensity in the previous five years, and modest reductions in 2006 and 2007 (see above). Analysis of energy-saving options (Lin et al. 2007) concludes that with vigorous policy action it could be possible to meet the 20 per cent energy intensity reduction target, but time clearly is running out for 2010 .

Nevertheless, the target of constraining growth in energy use to half the rate of GDP growth could be a useful yardstick in years to come, and could underpin a possible international commitment on national emissions by China.

\section{Possible commitments by China in an effective global mitigation regime}

Strong domestic policy action in China is likely to eventuate only if there is strong action in other major countries, especially the United States. Political change is under way in the United States, with growing support in Congress for domestic policies to control greenhouse gas emissions. Both presidential candidates for the upcoming election are running on platforms that include goals of reducing US emissions by 60 per cent (John McCain) and 80 per cent (Barack Obama) by 2050, compared with 1990 levels.

How far the negotiations under the UN 'Bali road-map'-or indeed any alternative negotiating framework - can take the world towards effective climate change mitigation depends in large measure on the commitments that China and the United States are prepared to make. China's dominance in global emissions and emerging importance as a global economic force mean that it is no longer credible to claim that mitigation has to be undertaken exclusively in industrialised countries. Effective mitigation of climate change will require global emissions to peak in the near future, and then decline to well below current levels (IPCC 2007). Given fast 
emissions growth in China and other developing countries, and their rapidly rising share in global emissions, emissions need to be limited and then reduced in all countries.

As argued by the Garnaut Climate Change Review (Garnaut 2008a), broad international acceptance of national emissions limits will require a heavy emphasis on per capita measures, leading ultimately to equal per capita emissions rights across all countries. This would have to be implemented gradually, and fast-growing countries close to the world average per capita emissions would need to be given some headroom to allow their emissions to go above the global average for a limited time. China is in this situation, with emissions per person soon to reach the global average on a fast-rising curve. Headroom could take the form of the emissionintensity target applying for a number of years, before shifting to a trajectory of reductions in per capita emissions.

Consistent with this, a first and significant step for China would be to hold the growth in its carbon dioxide emissions to half the rate of its GDP growth, as shown by Trajectory A in Figure 8.6. This would be consistent with China's announced policy for halving its energy intensity by 2020, and increased use of renewable and other low-emissions energy to counterbalance increases in high-emissions coal. Over time, adherence to this trajectory would drive emission levels significantly below business-as-usual levels. In 2030, China's fossil-fuel emissions would be almost one-third lower than in the business-as-usual case-and the same as they would be in 2021 without policy action (Figure 8.6).

At some point, China's scope for headroom would come to an end, and China's per capita emissions would need to start to fall. The second trajectory (B) in Figure 8.6 illustrates such a contraction scenario, which takes over from the 'half GDP growth' trajectory in 2020. The scenario shows China's emissions for a linear reduction in per capita emissions-or emissions entitlements, if there were international trade in entitlements - towards 3 tonnes per person in 2050 (3 tonnes per person is mentioned as a 2050 global goal by Stern [2008] and is used here to illustrate the sort of long-term emissions reductions that will be required). Trajectory $B$ implies an approximately 2 per cent reduction rate in annual absolute emissions entitlements in the 2020s. It would bring emissions (entitlements) back to 2012 levels by 2030-a 60 per cent reduction relative to business as usual.

Even this level of mitigation by China might not suffice. Garnaut et al. (2008) analyse what would be required to adhere to a limited stabilisation path (aiming not to exceed an atmospheric concentration of 550 parts per million of carbon dioxide). Assume that industrialised and transition countries (the so-called 'Annex 1' countries of the United Nations Framework Convention on Climate Change) reduce emissions by 30 per cent by 2020 (the upper bound of the range of emissions reductions by 2020 proposed by the European Union). This gives room for the emissions of developing countries to increase by an annual average of only 1.4 per cent to 2020. The figure of 1.4 per cent is not much more than the rate of population growth for the developing world, and well below the 4 per cent annual growth in emissions assumed for China to 2020, under 
Figure 8.6 China's future emissions or emission entitlements under different scenarios, 2000-2030

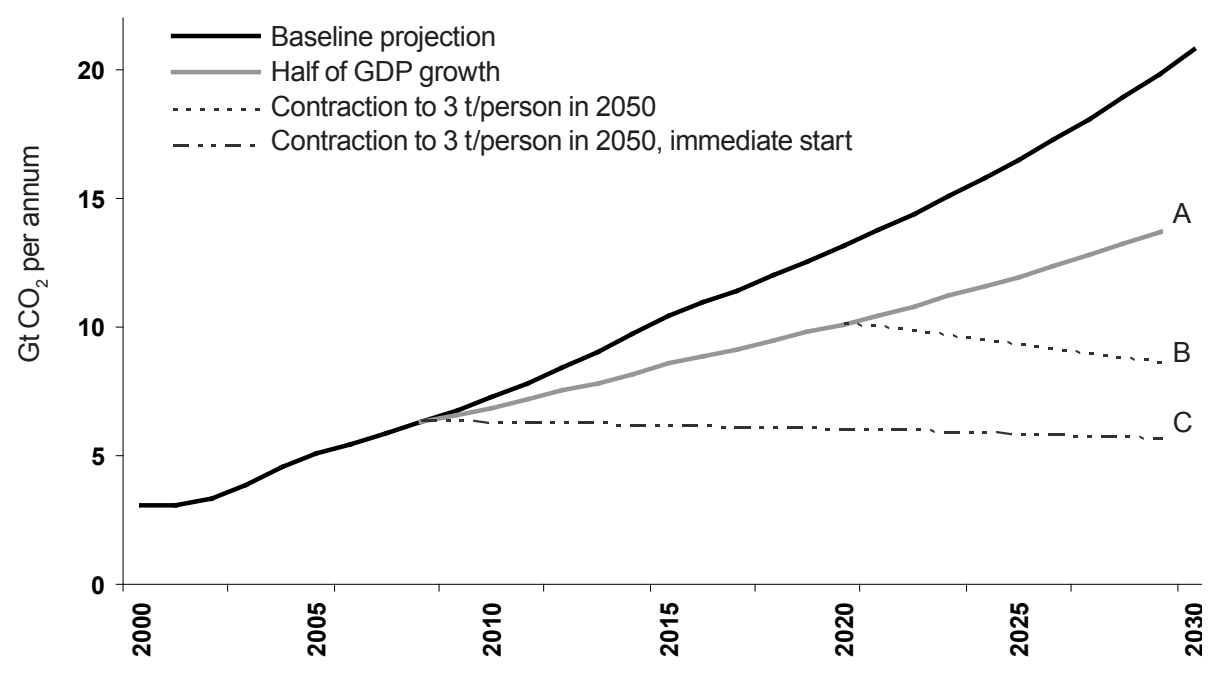

the intensity target.

Trajectory $C$ in Figure 8.6 shows the emissions path for China in a case in which per capita emissions contract from their current level towards the 3 tonnes of carbon dioxide target for 2050, starting in 2009. While it is not realistic to assume that China does not need any headroom and can start to cut emissions immed-iately, this trajectory provides a useful illustrative bound on its possible mitigation effort.

Whether and where China lies between its business-as-usual baseline and the most stringent mitigation trajectory (C) will depend on whether and to what extent it chooses to participate in the global mitigation regime. This in turn will be a function of industrial-country participation and pressure, China's assessment of the political and economic benefits of participation and nonparticipation and the give and take of international negotiations. Most importantly, it will depend on China's own assessment of the importance of avoiding high risks of dangerous climate change.

Realising any of mitigation Trajectories A, B or C would require strong policy action, including for fuel switching away from coal, expansion of renewable and/or nuclear power, geosequestration for carbon dioxide (carbon capture and storage) when and where available, and accelerated structural change and improvements in energy efficiency throughout the economy. It could, however, be less difficult to achieve than it appears at first sight. Rapid projected 
emissions growth presents great opportunities, because much of China's infrastructure is not yet in existence. The additional costs of building new power supply systems, manufacturing industries or transport infrastructure to a low-carbon standard are much lower than refurbishing or replacing existing stocks, which would be needed to achieve similar reductions in slowergrowing economies.

Comprehensive emissions pricing, through a tax or an emissions trading scheme, would be the most economically efficient way of achieving this outcome. International harmonisation of marginal abatement costs would allow emissions reductions at least at cost. Linking to international emissions markets, which are emerging or expanding in the European Union, the United States, Japan, Australia, New Zealand and probably in other countries in future, could achieve this for China. Depending on the allocation of emissions entitlements, this could benefit China economically even without taking into account the benefits from lesser climate change impacts and risks. The International Monetary Fund's World Economic Outlook (IMF 2008), for example, shows simulations in which China's consumption increases significantly, if allocations are made on the basis of current emissions or population. China could sell excess emissions entitlements if remaining below its agreed trajectory of emissions entitlements, or dampen compliance costs by buying entitlements elsewhere-a realistic scenario once developing countries start coming into an international system.

Emissions trading will be critical to providing incentives for China and other developing countries to participate in the international mitigation regime, but it is only one part of the story. Increased industrial-country financing of the research, development and commercialisation of low-emissions technology, as well as the financing of the transfer of this technology to developing countries, will be critical.

\section{Conclusion}

It is in China more than anywhere else that global climate change mitigation will be decided. If China does not participate in the global mitigation effort, its emissions will continue to grow rapidly and will account for a rising share of global emissions. Many 'mainstream' analyses underestimate likely economic growth in years to come, and could be too optimistic about reductions in the energy intensity and carbon intensity of China's energy system, unless there are strong and comprehensive policies to reduce emissions. Indeed, with high oil prices, there might be a strong shift to coal, which will further increase the rate of growth in emissions. ${ }^{9}$

Moreover, if China does not participate, or only participates marginally, in the global mitigation effort, there will be an indirect effect that will see other countries reduce their levels of ambition and effort since they will know that, without China, their efforts cannot avert climate change risks. On the other hand, if China does participate fully in global mitigation efforts, these two effects can be reversed. China's own emissions will be much lower, and other countries_-industrialised and developing —are likely to do more. 
China is starting to put a range of ambitious climate change policies in place, and has announced goals of reducing the energy intensity of the economy and increasing the share of low-emissions energy. If implemented, these policies will limit emissions growth to well below the business-as-usual trajectory. China's goal of limiting the growth in energy use to half the growth rate of the economy could become the basis for a near-term emissions target that will allow it to play a leading role in international discussions. Constraining the growth of China's emissions in this way could be compatible with the start-up phase of an international system of per capita emissions converging to a common and lower level, with some headroom provided in the interim for fast-growing developing countries.

\section{Notes}

1 The Kaya identity further decomposes economic growth into population growth and growth in income per capita.

2 Since energy intensity and carbon intensity are declining, acceleration for them means that they are declining less rapidly.

3 Growth in other greenhouse gas emissions is thought to be much slower. Emissions of methane and nitrous oxide, which account for about one-sixth of China's emissions in carbon dioxide equivalent terms, are reported to have grown by only 0.6 per cent per annum from 1994 to 2004 (NDRC 2007).

4 In 2006, energy consumption grew by 9.6 per cent, and GDP by 11.6 per cent (NBS 2007a, 2008a).

5 See NBS (2007b).

6 This section draws heavily on Garnaut et al. (2008).

7 We extend the latter projection to 2030.

8 The IEA projects an annual average decline of 1.8 per cent for energy intensity in the developing world excluding China in the next 25 years.

9 China is investing in coal-to-liquid plants and is expected to start operating the largest such facility outside South Africa later in 2008. See Nakanishi and Niu (2008).

\section{References}

Auffhammer, M. and Carson, R.T., 2008. 'Forecasting the path of China's $\mathrm{CO}_{2}$ emissions using province-level information', Journal of Environmental Economics and Management, doi:10.1016/j.jeem.2007.10.002.

Cooper, R., 2004. A carbon tax for China. Available from http://www.economics. harvard.edu/faculty/cooper/papers_cooper (accessed 20 June 2008).

Downs, E.S., 2004. 'The Chinese energy security debate', The China Quarterly, 177:21-41.

Fisher-Vanden, K., Jefferson, G.H., Liu, H. and Tao, Q., 2004. 'What is driving China's decline in energy intensity?', Resource and Energy Economics, 26(1):77-97.

Garnaut, R. and Huang, Y., 2005. 'Is growth built on high investment sustainable?', in R. Garnaut and L. Song (eds), The China Boom and its Discontents, Asia Pacific Press and ANU E Press, The Australian National University, Canberra:1-18. 
_- 2007. 'Mature Chinese growth leads the global Platinum Age', in R. Garnaut and Y. Huang (eds), China: linking markets for growth, Asia Pacific Press and ANU E Press, The Australian National University, Canberra:9-29.

Garnaut, R., 2008a. Interim Report to the Commonwealth, State and Territory Governments of Australia, February. Available from www.garnautreview. org.au.

- - 2008b. Measuring the immeasurable: the costs and benefits of climate change mitigation, The Sixth H.W. Arndt Memorial Lecture, The Australian National University, Canberra, 5 June.

Garnaut, R., Howes, S., Jotzo, F. and Sheehan, P., 2008 (forthcoming). Emissions in the Platinum Age: the implications of rapid development for climate change mitigation, Background Working Paper for the Garnaut Climate Change Review, Oxford Review of Economic Policy.

International Energy Agency (IEA), 2007a. World Energy Outlook 2007: China and India insights, International Energy Agency, Paris.

- - 2007b. $\mathrm{CO}_{2}$ Emissions from Fuel Combustion, International Energy Agency, Paris.

International Monetary Fund (IMF), 2008. World Economic Outlook 2008, International Monetary Fund, Washington, DC.

Intergovernmental Panel on Climate Change (IPCC), 2007. Fourth Assessment Report, Working Group III, Intergovernmental Panel on Climate Change, Cambridge University Press, Cambridge, Mass.

Kaya, Y. and Yokobori, K. (eds), 1997. Environment, Energy, and Economy: strategies for sustainability, United Nations University Press, Tokyo.

Lin, J., Zhou, N., Levine, M.D. and Fridley, D., 2007. Achieving China's Target for Energy Intensity Reduction in 2010: an exploration of recent trends and possible future scenarios, China Energy Group, Lawrence Berkeley National Laboratory, Berkeley.

Maddison, A., 2001. The World Economy: a millennial perspective, Organisation for Economic Cooperation and Development, Paris.

MNP (Netherlands Environmental Assessment Agency), 2008. Global $\mathrm{CO}_{2}$ emissions: increase continued in 2007, Netherlands Environmental Assessment Agency, Bilthoven. Available from http://www.mnp.nl/en/ publications/2008/globalco2emissionsthrough2007.html.

Nakanishi, N. and Niu, S., 2008. 'China builds plant to turn coal into barrels of oil', Reuters, 4 June.

National Bureau of Statistics, 2007a. 2007 China Statistical Yearbook, China Statistics Press, Beijing.

National Bureau of Statistics, 2007b. Communiqué on National Energy Consumption for Unit GDP in the First Half of 2007, 2007-07-31. http://www. 
stats.gov.cn/english/newsandcomingevents/t20070731_402422194.htm

National Bureau of Statistics (NBS), 2008a. Announcement on verified GDP data in 2006 and 2007, National Bureau of Statistics, Beijing. Available from http:// www.stats.gov.cn/english/newsandcomingevents/t20080410_402473201.htm (accessed 10 April 2008).

- - , 2008b. Statistical communique of the People's Republic of China 2007, 28 February. Available from http://www.stats.gov.cn/english/ newsandcomingevents/t20080228_402465066.htm.

Development Research Center, 2005. China National Energy Strategy and Policy 2020, Development Research Center of the State Council, Beijing. Available from http://www.efchina.org/FReports.do?act=detail\&id=155.

National Development Research Commission (NDRC), 2007. China's National Climate Change Program, National Development and Reform Commission, Beijing.

Perkins, D. and Rawski, T., 2008. 'Forecasting China's economic growth over the next two decades', in L. Brandt and T.G. Rawski (eds), China's Great Economic Transformation, Cambridge University Press, Cambridge, Mass.

Pew Center, 2007. Climate Change Mitigation Measures in the People's Republic of China, Pew Center on Global Climate Change, Arlington.

Quadrelli, R. and Peterson, S., 2007. 'The energy-climate challenge: recent trends in $\mathrm{CO}_{2}$ emissions from fuel combustion', Energy Policy, 35(11):5938.

Raupach, M.R., Marland, G., Ciais, P., Le Quere, C., Canadell, J.G., Klepper, G. and Field, C.B., 2007. 'Global and regional drivers of accelerating $\mathrm{CO}_{2}$ emissions', Proceedings of the National Academy of Sciences, 0700609104.

Sheehan, P. and Sun, F., 2007. Energy use and $\mathrm{CO}_{2}$ emissions in China: interpreting changing trends and future directions, CSES Climate Change Working Paper No.13, Centre for Strategic Economic Studies, Victoria University, Melbourne.

Sinton, J.E. and Fridley, D.G., 2000. 'What goes up: recent trends in China's energy consumption', Energy Policy, 28(10):671-87.

Stern, N., 2008. Key Elements of a Global Deal on Climate Change, London School of Economics, London.

Wu, L., Kaneko, S. and Matsuoka, S., 2005. 'Driving forces behind the stagnancy of China's energy-related $\mathrm{CO}_{2}$ emissions from 1996 to 1999: the relative importance of structural change, intensity change and scale change', Energy Policy, 33(3):319-35. 
China's rapid emissions growth and global climate change policy 